\title{
PENETAPAN BRAND AMBASSADOR SEBAGAI UPAYA STRATEGI KOMUNIKASI PEMASARAN "RUANGGURU” DI ERA PANDEMI COVID-19
}

\author{
Ni Putu Stiti Ayuningtyas'1), Ni Luh Putu Sariani'2), Desak Made Sukarnasih²) \\ 1)Program Studi IImu Komunikasi, Fakultas Hukum dan Ilmu Sosial, Universitas Pendidikan Nasional, Denpasar, Bali, \\ Indonesia \\ ${ }^{2)}$ Program Studi Manajemen, Fakultas Ekonomi dan Bisnis, Universitas Pendidikan Nasional, Denpasar, Bali, Indonesia
}

Corresponding author : Ni Putu Stiti Ayuningtyas

E-mail : stitiayuningtyas.ilkom2018@gmail.com

\section{Diterima 06 September 2021, Direvisi 16 September 2021, Disetujui 16 September 2021}

\begin{abstract}
ABSTRAK
Kegiatan pembelajaran saat pandemi di Indonesia dilakukan secara daring. Perlu adanya dukungan media pembelajaran seperti yang disediakan oleh Ruang guru. Ruang guru merupakan penyedia media pembejaran yang bisa diakses menggunakan internet, sehingga memudahkan guru dan siswa saat proses belajar. Dengan persaingan yang terus bertumbuh, Ruang guru perlu memilih strategi komunikasi pemasaran yang tepat, salah satunya dengan menunjuk brand ambassador. Tahun 2021, telah dipilih lima brand ambassadors baru yang berasal dari kalangan artis. Pengabdian dilakukan untuk mengetahui perkembangan strategi komunikasi pemasaran Ruang guru melalui pemilihan brand ambassadors dan seperti apa respon masyarakat terkait hal tersebut. Metode pengabdian melalui proses tahapan, pelaksanaan, dan evaluasi. Diketahui bahwa masyarakat setuju akan terpilihnya brand ambassador Ruangguru 2021 dan dinilai mampu meningkatkan positif perusahaan. Teori strategi komunikasi pemasaran yang dilakukan adalah pull, push, dan profle strategies. Hasil akhir kegiatan PKL menunjukkan sebanyak 40 responden setuju atas pemilihan brand ambassador, diantaranya $28 \%$ memilih Prilly Latuconsina sebagai "ikon" Ruang guru paling sesuai. Selain itu, banyak pengguna yang setuju atas terpilihnya kelima brand ambassadors karena prestasi serta rekam jejak yang baik dari masing-masing brand ambassador. Saran yang dapat diberikan adalah kedepannya Ruang guru harus lebih meningkatkan kualitas konten dan lebih selektif memilih brand ambassador agar sesuai dengan visi dan misi perusahaan.
\end{abstract}

Kata kunci: brand ambassador; pemasaran; ruang guru.

\begin{abstract}
Learning activities during the pandemic in Indonesia are carried out online. There needs to be support for learning media such as those provided by Ruang guru. With the high rivalry in this industry, Ruangguru needs to choose the right marketing communication strategy, one of which is by appointing a brand ambassador. In 2021, five new brand ambassadors have been selected from among the artists. This community dedication held to know the effect of Ruang guru's brand ambassadors and what's public responses to it. The method is through a process of stages, implementation, and evaluation. The marketing communication strategies used are pull, push, and profile strategies. The final result showed that 40 respondents agreed with the selection of brand ambassadors and they be able to increase the company's positivity and of which $28 \%$ chose Prilly Latuconsina as the most compatible Ruang guru "icon". In addition, many users agree with the selection of the five brand ambassadors because of the achievements and good track records of each brand ambassador. Recommendations that can be given are that in the future Ruang guru should further improve the quality of content and be more selective in choosing brand ambassadors to fit in the company's vision and mission.
\end{abstract}

Keywords: brand ambassador; marketing; ruang guru.

\section{PENDAHULUAN}

Pertengahan Tahun 2021, Pandemi

Covid-19 di Indonesia masih belum menunjukkan perkembangan yang baik. Hal tersebut ditandai dengan masih terus terjadinya trend peningkatan kasus di beberapa wilayah Indonesia. Pernyataan tersebut diperkuat dengan data yang dihimpun per tanggal 14 Juli 2021, kasus penyebaran Covid-19 di Indonesia telah mencapai 2.670.046 orang terhitung sejak kasus pertama diumumkannya oleh Presiden Joko Widodo pada 2 Maret 2020. Dari total kasus tersebut, tercatat sejumlah 2.157.363 orang telah dinyatakan sembuh dan meninggal 
dunia sejumlah 69.210 orang (Muhamad, 2021). Upaya pemerintah untuk terus menekan penurunan kasus juga terus dilakukan, seperti melakukan Pemberlakukan Pembatasan Kegiatan Masyarakat (PPKM). Upaya pemerintah untuk terus menekan penurunan kasus juga terus dilakukan, seperti melakukan Pemberlakukan Pembatasan Kegiatan Masyarakat (PPKM).

Adanya pandemi Covid-19 di Indonesia ini tentu memengaruhi banyak sektor kehidupan masyarakat, tidak terkecuali sektor pendidikan. Salah satu dampak perubahan dalam sektor pendidikan adalah dengan memberlakukan pembelajaran jarak jauh yang mengharuskan guru dan siswa melakukan kegiatan belajar-mengajar dari rumah saja. Berdasarkan hal tersebut, maka pihak guru maupun siswa dituntut untuk memahami sistematika pembelajaran secara daring (online) dengan memanfaatkan teknologi dan informasi yang ada saat ini. Tentunya latar belakang perubahan dinamika pembelajaran tersebut dipengaruhi oleh adanya Surat Edaran Nomor 4 Tahun 2020 tentang Pelaksanaan Kebijakan Pendidikan dalam Masa Darurat Penyebaran Covid-19 yang diputuskan oleh Menteri Pendidikan dan Kebudayaan Republik Indonesia (Basar, 2021).

Berdasarkan hasil pengamatan sementara penulis melalui pemberitaan media online, pengalaman individu dalam proses pembelajaran secara daring (online), hingga melakukan observasi di lapangan dengan objek siswa-siswi yang melakukan pembelajaran jarak jauh di Denpasar, maka dapat diberikan sedikit gambaran awal bahwasanya banyak terjadi perubahan perilaku pelajar dalam melakukan kegiatan belajar. Perubahan tersebut ditandai dengan berubahnya media pembelajaran yang digunakan serta proses komunikasi yang berlangsung saat proses pembelajaran. Selain karena tuntutan upaya penurunan kasus Covid-19, kemajuan teknologi juga memengaruhi perubahan pesat pada dinamika budaya dan komunikasi belajar di Indonesia. Proses komunikasi jarak jauh tanpa adanya tatap muka antara guru dan siswa dengan memanfaatkan media digital tentunya belum terbayang pada rentang waktu 10 maupun 20 tahun yang lalu. Perubahan serta perkembangan dinamika proses pembelajaran tersebut kini telah berubah menjadi "Edutaiment" dari yang sebelumnya pendidikan hanya sebatas "Education" (Afif, 2019). Perubahan tersebut sesungguhnya tetap bertujuan untuk melakukan proses pembelajaran dan tetap terjadi proses komunikasi antara tenaga pengajar dan siswa, hanya saja setelah masa pandemi ini, proses pembelajaran berubah dari segi perencanaan, strategi pembelajaran, teknik pengajaran, serta metode pelaksanaannya.

Dengan adanya perubahan kebiasaan atau perilaku belajar-mengajar antara guru dan siswa tersebut, maka ditemukan beberapa permasalahan pada proses pembelajaran daring (online). Namun, sesungguhnya kegiatan pembelajaran secara daring (online) tidak hanya dilakukan beberapa waktu ke belakang saja. Universitas Terbuka merupakan salah satu lembaga pendidikan perguruan tinggi yang sedari awal telah menerapkan pembelajaran secara daring (online). Pembelajaran yang dilakukan oleh pihak Universitas Terbuka meliputi bantuan belajar dalam bentuk tutorial tatap muka, tutorial online, dan tutorial tertulis. Bentuk tutorial tatap muka merupakan bimbingan belajar yang paling utama (Pakpahan, 2011). Selain kegiatan belajar-mengajar dilakukan secara daring, pihak Universitas Terbuka juga tetap menyelenggarakan kegiatan praktikum untuk menunjang pemahaman mahasiswa terkait pembelajaran yang diberikan. Berdasarkan hasil penelitian yang didapatkan oleh (Pakpahan, 2011), dominan gaya belajar yang ditunjukkan oleh mahasiswa UPBJJ-UT (Unit Program Belajar Jarak Jauh-Universitas Terbuka) Medan adalah membaca dengan syarat dilampirkannya visualisasi materi pembelajaran yang menarik dan sesuai. Akan tetapi, dalam penelitian tersebut, informan merasa menemui permasalahan mengenai kurang menariknya tutorial pembelajaran melalui video yang dilampirkan. Oleh sebab itu, dalam proses pembelajaran jarak jauh maupun secara daring, harus diperhatikan bagaimana kualitas konten yang hendak ditampilkan agar target audience dapat memahami maksud dan tujuan dari video yang dilampirkan. Pernyataan tersebut diperkuat dengan penelitian yang dilakukan oleh (Susanti et al., 2018), menyatakan dalam aspek student engagement, video yang efektif digunakan untuk metode pembelajaran adalah video yang singkat namun harus memperhatikan penggunaan bahasa, tempo bicara, penggunaan ilustrasi pemecahan masalah.

Ditinjau melalui hasil penelitian yang dilakukan oleh (Basar, 2021), ditemukan keluhan oleh siswa di SMPIT Nurul Fajri, Cikarang Barat, Bekasi yang kurang memahami isi daripada materi yang disampaikan oleh guru. Hal tersebut dikarenakan konten pembelajaran yang disediakan kurang menarik dan kesediaan jaringan internet yang belum maksimal. Dari seluruh siswa SMPIT Nurul Fajri, Cikarang Barat, Bekasi yang diteliti, sebanyak $51 \%$ siswa tidak tertarik melakukan pembelajaran jarak 
jauh secara daring (online) dan hanya 4\% dari populasi menyatakan sangat tertarik. Tentu kesenjangan persentase tersebut menjadi tolak ukur untuk terus membenahi metode dan media pembelajaran yang hendak diterapkan oleh tenaga pengajar dan penyedia layanan pendidikan di Indonesia. Selain itu, berdasarkan hasil observasi secara langsung oleh penulis kepada beberapa siswa-siswi di Kota Denpasar, dapat dinyatakan bahwasanya banyak yang mengeluhkan jenuh dengan proses pembelajaran jarak jauh dan berharap adanya modifikasi penyediaan konten pembelajaran, misalnya dengan membuat tayangan slides presentasi yang menarik, upaya komunikasi antara guru dan siswa menjadi lebih efektif dan berkesinambungan.

Berdasarkan atas permasalahan yang ditemukan, penulis juga menemukan adanya solusi atas permasalahan tersebut, seperti adanya layanan pendidikan melalui platform aplikasi Ruangguru sebagai tambahan media pembelajaran yang dapat digunakan untuk menunjang minat belajar siswa di kelas. Ruangguru merupakan sebuah perusahaan teknologi yang berfokus untuk menyediakan layanan berbasis pendidikan yang ditujukan untuk meningkatkan proses belajar seorang pelajar. Sejak berdiri tahun 2014, Ruangguru telah banyak melakukan upgrade layanan dengan terus berupaya memperbanyak konten video pembelajaran, memilih brand ambassador yang dinilai dapat merepresentasikan tokoh pendidikan yang tepat di Indonesia, menyediakan berbagai macam fitur yang dapat membantu kegiatan belajar-mengajar, hingga menjaring lebih banyak tenaga pengajar profesional di bidangnya.

Selain terus berinovasi dengan menyajikan video materi pembelajaran yang edukatif dan interaktif, aplikasi Ruangguru juga memiliki sejumlah keunggulan dibandingkan kompetitor lain, diantaranya terdapat layanan bimbingan belajar Brain Academy yang dapat menggabungkan sistematika pembelajaran secara online dan offline (tatap muka) dengan guru-guru terbaik pilihan tim Ruangguru (Agustin, 2020). Layanan yang diberikan pada program Brain Academy kelas offline diantaranya smart classroom, cozy lounge, modern cafe, creative studio, mushola dan klinik PR, dengan tujuan agar setiap peserta didik dapat meningkat semangat serta kemampuannya dalam menumbuhkan minat belajar. Berdasarkan hasil penelitian yang dilakukan oleh (Agustin, 2020), menyatakan bahwa sebanyak 7 dari 10 siswa sekolah dasar di daerah Yogyakarta telah mengalami peningkatan hasil belajar setelah menggunakan fasilitas yang ditawarkan oleh Ruangguru.

Berbagai macam upaya strategi komunikasi pemasaran dilakukan oleh Ruangguru. Salah satunya adalah dengan memilih brand ambassador yang dapat menarik minat serta simpati masyarakat untuk memilih Ruangguru sebagai media pembelajaran saat ini. Bulan Juli 2021, pihak Ruangguru mengumumkan terpilihnya lima brand ambassador baru yang diharapkan mampu meningkatkan kinerja Ruangguru. Kelima brand ambassador tersebut diantaranya adalah Angga Yunanda, Fiki Naki, Prilly Latuconsina, Amanda Manopo, dan juga Baim Wong

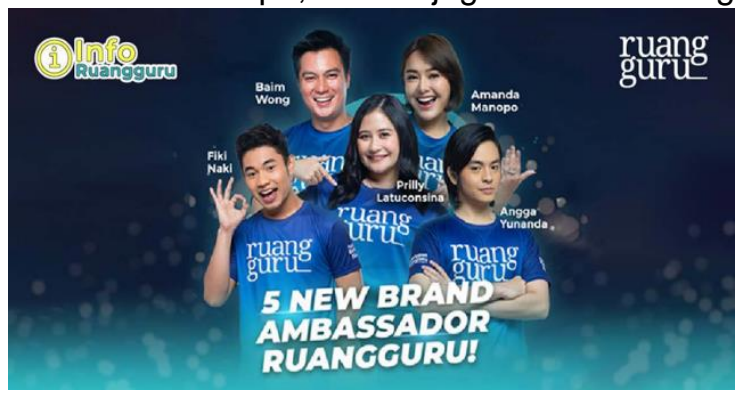

(Puspitasari, 2021).

\section{Gambar 1. New Brand Ambassador Ruangguru 2021 \\ (Sumber:https://www.ruangguru.com)}

Tidak hanya melakukan update brand ambassador saja, namun Ruangguru juga terus memberikan promo menarik yang dapat secara langsung dilihat melalui laman https://www.ruangguru.com/promo. Tentu dengan banyaknya upaya strategi komunikasi yang dilakukan, terdapat berbagai macam respon atau feedback dari konsumen maupun calon konsumen yang dituju. Oleh sebab itu, pada kegiatan Praktek Kerja Lapangan secara daring (online) ini, penulis hendak menganalisis bagaimana perkembangan strategi komunikasi pemasaran melalui pemilihan brand ambassador dan iklan oleh pihak Ruangguru pada Tahun 2020-2021 serta seperti apa tanggapan masyarakat awam dan pelanggan setia Ruangguru setelah adanya penetapan kelima new brand ambassador sebagai upaya promosi yang terus dilakukan oleh pihak Ruangguru di tengah pandemi Covid-19 ini. Adapun rentang waktu perkembangan Ruangguru yang akan dianalisis hanya berkisar pada Tahun 2020-2021, sesuai dengan awal mula perkembangan pandemi Covid-19 di Indonesia.

\section{METODE}

Kegiatan pengabdian masyarakat berupa Praktek Kerja Lapangan (PKL) ini dilakukan secara daring (online) dengan 
melakukan kegiatan analisis terkait suatu fenomena maupun permasalahan yang ada di suatu perusahaan. Kegiatan pengabdian masyarakat ini dilakukan dengan memilih objek tempat Praktek Kerja Lapangan (PKL) pada PT. Ruang Raya Indonesia atau biasa disebut dengan Ruangguru. Pelaksanaan kegiatan review perusahaan dilakukan kurang lebih selama 45 hari dan diselesaikan secara bertahap.

Metode pelaksanaan yang dilakukan untuk mencapai tujuan serta menjawab permasalahan yang hendak dibahas adalah dengan menggunakan metode persiapan, pelaksanaan, dan evaluasi. Penulis mengawali kegiatan pengabdian berupa analisis dengan memulai melakukan persiapan pengumpulan data sekunder seperti data terkait perusahaan PT. Ruang Raya Indonesia (Ruangguru) yang dapat diakses secara daring (online) melalui website resmi Ruangguru serta pengumpulan artikel media online ataupun jurnal-jurnal terakreditasi lainnya yang membahas tentang strategi komunikasi pemasaran PT. Ruang Raya Indonesia (Ruangguru). Setelah itu, pada tahap pelaksanaan, penulis melakukan analisis berdasarkan data sekunder yang telah terkumpul dan didukung dengan teori mengenai strategi komunikasi pemasaran. Penulis juga melakukan kegiatan wawancara kepada orang tua siswa dan siswa pengguna aplikasi Ruangguru serta pengisian data kuisioner yang diisi oleh 40 responden. Tahap terakhir merupakan tahap evaluasi. Penulis menarik kesimpulan dari hasil analisis yang telah dilakukan guna merangkum alasan dan pandangan pemilihan Brand Ambassador Ruangguru di tengah masyarakat.

\section{HASIL DAN PEMBAHASAN \\ Sejarah dan Layanan Ruangguru}

Ruangguru merupakan perusahaan yang berfokus dalam pemberian layanan pendidikan melalui pengembangan teknologi informasi dengan menggunakan video tutorial pada sebuah aplikasi. Perusahaan ini didirikan oleh anak Bangsa Indonesia, yakni Belva Devara dan Iman Usman pada tahun 2014. Tidak hanya cerdas, namun kedua generasi millennial tersebut mampu meraih prestasi dengan berhasil masuk ke dalam jajaran pengusaha sukses di bawah 30 tahun yang dirangkum oleh Forbes 30 under 30 di Asia (Shoumi, 2019).

Ruangguru menyediakan berbagai fitur layanan pendidikan yang bervariasi. Keseluruhan fitur tersebut dituangkan dalam bentuk video pembelajaran e-learning dengan sistem berlangganan, try-out ujian online dan tentunya telah bekerja sama dengan 32 dari 34
Provinsi di Indonesia pada tahun 2018 (Setiawati, 2019). Perkembangan positif yang terus ditunjukkan bersamaan dengan prestasiprestasi yang diraih oleh Ruangguru, membuat perusahaan ini dapat dipertimbangkan sebagai alternatif maupun pendamping metode dan media pembelajaran di berbagai sekolah di Indonesia. Terlebih pada saat pandemi, sekolah dituntut untuk melakukan pembelajaran jarak jauh yang tentunya merubah dinamika pembelajaran antara guru dan siswa dari yang sebelumnya dilakukan secara tatap muka menjadi menggunakan media perantara dengan bantuan jaringan internet.

Ruangguru tidak hanya peduli dengan perkembangan pendidikan di Indonesia, namun juga membantu masyarakat untuk meningkatkan kemampuan ekonomi melalui program kemitraan Ruangguru. Pengguna diajak untuk turut serta bergabung menjadi mitra Ruangguru yang tentunya mendapatkan keuntungan dengan memperoleh komisi setelah berhasil mengajak customer baru bergabung menjadi pengguna aplikasi Ruangguru. Komisi yang diperoleh mulai dari Rp50.000 per paket. Dengan membagikan kode mitra Ruangguru yang dimiliki kepada calon pengguna baru, maka akan mendapatkan komisi sesuai dengan paketpaket yang dipilihnya. Tidak hanya layanan tersebut, namun Ruangguru juga banyak menawarkan fitur layanan yang tentunya dapat menguntungkan kedua belah pihak.

Ruangguru terus melakukan terobosan-terobosan unik dan menarik. Pada tahun 2018, pihak Ruangguru melakukan penandatanganan MoU atau kerja sama dengan Pemerintah Kabupaten (Pemkab) Banyuwangi dalam pengadaan Ruangguru OnThe-Go (OTG). Program tersebut dimaksudkan untuk mendorong pemerataan pendidikan yang berkualitas hingga ke daerah pelosok desa. Pengadaan fitur layanan Ruangguru On-TheGo (OTG) sebagai upaya mendukung program Pemkab Banyuwangi, yakni "Smart Kampung" (Caturini, 2018). Kerja sama tersebut terjadi dikarenakan adanya kesamaan visi diantara keduanya, yakni dapat menjadi solusi untuk mengatasi kesulitan akses dan penyedia layanan pendidikan terutama di Indonesia.

Dilihat dari berbagai macam fitur layanan yang ditawarkan oleh Ruangguru dan pengguna yang telah mencapai 22 Juta masyarakat Indonesia pada Tahun 2021, maka dapat dinilai bahwasanya Ruangguru telah mampu menjadi solusi di tengah perubahan metode dan cara pembelajaran di Indonesia pada saat pandemi seperti saat ini di Tahun 2021. 
Strategi Komunikasi Pemasaran Ruangguru Untuk menunjang pemasaran, Ruangguru kerapkali membuat acara yang disiarkan langsung di televisi dan juga memilih brand ambassador atau ikon Ruangguru dari kalangan artis. Pada tahun 2021, Ruangguru kembali mengumumkan penetapan kelima new brand ambassadors diantaranya Angga Yunanda, Amanda Manopo, Baim Wong, Fiki Naki, dan Prilly Latuconsina.

Brand ambassador merupakan ikon pemasaran dari sebuah produk maupun menjadi identitas sebuah perusahaan yang bertugas untuk menjadi alat pemasaran guna mencapai kejayaan dan komersialisasi suatu produk (Putra, 2014). Lea-Greenwood (2013), menyatakan bahwasanya manfaat utama daripada dukungan selebriti brand ambassador adalah sebagai: "Press coverage, Changing perceptions of the brand, Attracting new customers, and Freshening up an existing campaign.", atau dapat diterjemahkan menjadi juru bicara pada saat dilakukannya liputan pers, merubah persepsi suatu brand di masyarakat, menarik simpati calon pelanggan baru, dan melakukan pembaharuan dalam pelaksanaan

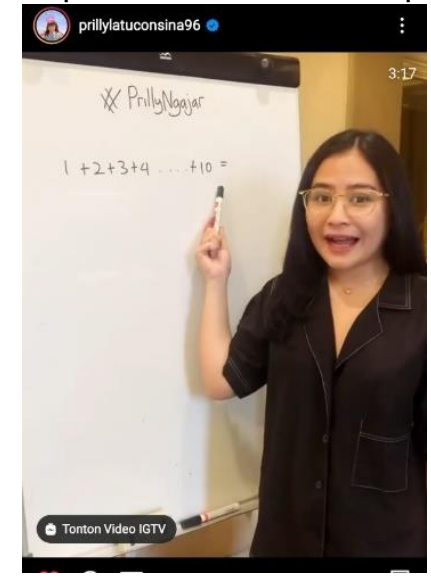

kampanye brand yang ada.

Gambar 2. Prilly sebagai Brand Ambassador
Ruangguru melakukan tutor online di laman Instagramnya

(Sumber:

www.instagram.com/prillylatuconsina96)

Pada perusahaan Ruangguru, peran seorang brand ambassador adalah menjadi ikon dalam kegiatan pemasaran serta bertugas untuk merepresentasikan visi dan misi perusahaan dalam bentuk kegiatan nyata di dunia pendidikan seperti ikut andil mengambil bagian sebagai tutor pengajar di Ruangguru dan aktif melakukan interaksi bersama pengguna dalam berbagai digital platform yang ada. Prilly Latuconsina atau yang akrab disapa Illy merupakan salah satu New Brand Ambassador Ruangguru Tahun 2021. Dalam beberapa kesempatan, Prilly aktif berinteraksi dengan pengikut di laman Instagram dengan jumlah 42,5 Juta followers yang dimilikinya. Bertajuk \#PrillyNgajar, Prilly mengambil peranan untuk mengedukasi pengikut Instagram yang juga dapat menjadi target calon pengguna Ruangguru baru untuk mudah mempelajari materi-materi terkait Matematika yang diajarkan oleh Prilly dalam segmen tersebut. Unggahan \#PrillyNgajar tersebut telah ditonton sebanyak 3.685 .790 kali per tanggal 28 Juli 2021.

Terdapat banyak faktor dalam memilih brand ambassador perusahaan Ruangguru diantaranya harus merupakan sosok yang dapat merepresentasikan keseimbangan antara dunia pendidikan dan karir. Dalam artian sosok brand ambassador yang didaulat harus mampu menjadi contoh pengguna Ruangguru agar tidak mengesampingkan pendidikan saat melakukan aktivitas dan profesi apapun. Di tahun 2018, Ruangguru menetapkan lqbaal Ramadhan (21) sebagai Brand Ambassador Ruangguru. lqbaal merupakan aktor sekaligus mantan penyanyi boyband Coboy Junior. Banyak prestasi yang ditorehkan oleh lqbaal, salah satunya adalah berhasil membintangi film layar lebar fenomenal berjudul Dilan 1990 maupun Dilan 1991 dan Bumi Manusia yang diadaptasi dari buku milik Pramoedya Ananta Toer. Selain bernyanyi dan bermain peran, lqbaal juga tidak melupakan tugasnya dalam menimba ilmu. Pada tahun 2018, Iqbaal berhasil lulus program pendidikan pre-college selama hampir dua tahun di United World Colleges (UWC) Montezuma, New Mexico, USA (Kurniandari, 2018).

Tahun 2019, Ruangguru kembali mengangkat beberapa brand ambassador bertepatan dengan perayaan ulang tahun ke-5 Ruangguru. Beberapa public figure yang terpilih diantaranya Naura, Anneth Idol Cilik, dan Nashwa Zahira. Ketiga sosok tersebut 
merupakan perempuan muda hebat yang berkecimpung dalam dunia tarik suara sejak usia belia. Kepribadian yang ramah dan ceria tentunya menggambarkan bagaimana dunia pendidikan harus dijalankan dengan suka cita. Seluruh brand ambassador yang terpilih tentunya memiliki segudang prestasi yang mampu dijadikan panutan di kalangan generasi millenials dan gen $Z$ saat ini.

Pada tahun 2020, Ruangguru kembali menambah pasukan brand ambassador. Berbeda dengan tahun-tahun sebelumnya, tahun 2020 Ruangguru tidak hanya mengangkat brand ambassador dari kalangan usia remaja, namun juga dewasa. Keempat brand ambassador Ruangguru terpilih di tahun 2020 diantaranya Nissa Sabyan, keluarga Ruben Onsu, karakter animasi dalam series Nussa dan Rara, dan Putri Ariani yang merupakan pemenang ajang Indonesia's Got Talent tahun 2014 (Hidayat, 2020). Tentu yang jadi sorotan adalah pemilihan keluarga Ruben Onsu. Hal tersebut dikarenakan besarnya atensi pada keluarga tersebut tentunya mampu meningkatkan promosi dan penyampaian informasi brand Ruangguru dengan jangkauan yang luas.

Terakhir, pada tahun 2021, Ruangguru kembali menambah jajaran brand ambassador diantaranya Amanda Manopo, Angga Yunanda, Baim Wong, Fiki Naki, dan juga Prilly Latuconsina. Banyak respon positif dari masyarakat yang mengapresiasi keputusan daripada pihak Ruangguru dalam penetapan brand ambassador Ruangguru tahun 2021. Hal tersebut dikarenakan masing-masing brand ambassador dikenal aktif dalam kegiatan sosial, karir, dan pendidikannya. Melalui pemaparan tersebut, dapat diketahui bahwasanya pemilihan brand ambassador yang sesuai terus dilakukan oleh pihak Ruangguru dan merupakan stratehi komunikasi pemasarannya.

Strategi merupakan perencanaan dalam kegiatan manajemen guna mencapai sebuah tujuan individu maupun kelompok. Maka, definisi sederhana dari strategi komunikasi pemasaran adalah panduan dari perencanaan komunikasi pemasaran atau marketing dari sebuah brand maupun perusahaan untuk mencapai tujuan tertentu yang telah ditetapkan (Sarastuti, 2017). Adapun tiga elemen dasar dari strategi komunikasi pemasaran yang dikenal sebagai STP yakni segmentation, targeting, dan positioning.

Strategi komunikasi pemasaran dapat diterapkan melalui perantara media sosial yang disampaikan melalui digital platform seperti penggunaan aplikasi Instagram, Twitter, dan Facebook. Hasil yang didapat melalui kegiatan pemasaran dengan menggunakan media sosial diantaranya increased brand awareness, improved reputation, increased relation- ship, brand development, dan increases purchase intention (Moriansyah, 2015).

Dalam penyebar luasan informasi pemasaran dengan menggunakan produk media massa, maka peran daripada brand ambassador sebagai komunikator sangat penting. Menurut teori dependensi media atau teori ketergantungan media, menyatakan bahwa semakin seseorang tergantung pada suatu media untuk memenuhi keperluannya, maka media akan semakin bernilai untuk orang tersebut serta memperlihatkan bahwa individu bergantung pada media untuk pemenuhan kebutuhan dan mencapai tujuannya, tetapi mereka tidak bergantung pada banyak media dengan porsi yang sama besar (Krisnawati. et all, 2016). Berdasarkan atas konsep dasar teori ketergantungan media atau dependensi media tersebut, maka seorang pelajar maupun mahasiswa yang tengah dihadapkan pada problematika pembelajaran jarak jauh cenderung akan mencari informasi mengenai pemecahan kesulitan dalam pembelajaran melalui jejaring media sosial. Menurut JooYoung \& Moro (2012) menyatakan "In the MSD view, media has two levels of dependency relations, i.e. with individuals (micro-level) and with other systems (macro-level), such as economic and political systems", atau jika diterjemahkan dapat berarti bahwa dalam perspektif teori dependensi media, media memiliki dua tingkatan hubungan yang dapat memengaruhi lingkup sistem ekonomi dan politik. Hal tersebut ditandai dengan media massa sebagai alat atau media promosi untuk membantu kegiatan ekonomi.

Dalam perusahaan Ruangguru, yang bertugas untuk menyampaikan informasi mengenai produk yang ditawarkan oleh Ruangguru kepada khalayak adalah brand ambassador melalui pemanfaatan media sosial.

Dalam konteks penerapan strategi komunikasi pemasaran, terdapat Teori STP (Strateging, Targeting, dan Positioning). Adapun penjabaran daripada tiga strategi dalam pemasaran brand Ruangguru, diantaranya:

1. Strategi menarik atau pull stategy yang bertujuan untuk memengaruhi pengguna brand sehingga memutuskan untuk melakukan pembelian produk. Fokus pesan terletak pada kualitas produk dan service kepada pelanggan. Hal ini sesuai denggan strategi komunikasi yang dilakukan oleh para Brand Ambassadors Ruangguru. Strategi 
menarik yang digunakan oleh New Brand Ambassadors Ruangguru adalah dengan melakukan promosi di media sosial. Hal yang dipromosikan adalah mencakup kualitas hingga layanan kepada para pelanggan. Ditengah pandemi Covid-19 saat ini, promosi dengan menggunakan media sosial adalah pilihan yang paling tepat. Degan menerapkan strategi menarik ini maka akan banyak masyarakat yang terpengaruh dengan adanya Ruangguru yang memberikan pelayanan terbaik kepada para pengguna. Sebagai contoh, penulis menggunakan dua orang dari kelima brand ambassadors terpilih, yaitu Angga Yunanda dan Prilly Latuconsina. Kedua artis ini tengah menjadi perbincangan lantaran prestasi yang diraih sangat luar biasa. Sebagai Brand Ambassador Ruangguru, Angga, Prilly, serta brand ambassador lain menggunakan media sosial untuk memperkenalkan ruangguru kepada masyarakat. Dengan menggunakan hastag \#anggangajar dan \#prillyngajar, Ruangguru siap berbagi informasi melalui akun pribadi.

2. Strategi mendorong atau push strategy yang bertujuan lebih membangkitkan keinginan konsumen untuk membeli produk melalui kegiatan-kegiatan inovatif yang dilakukan oleh ikon sebuah brand atau brand ambassador yang ditunjuk. Dalam pelaksanaan strategi mendorong ini tentu ditujukan untuk lebih memperkenalkan brand sehingga selalu dapat dijangkau informasinya oleh masyarakat. Menggunakan hastag \#selaluadaharapan, maka akan banyak akun yang dapat melihat unggahan dari pihak Ruangguru maupun brand ambassador. hingga dalam kegiatan mengenalkan brand ambassador juga mengunakan \#AnggaNgajar, \#PrillyNgajar, sehingga lebih meyakini bahwa perusahaan memilih brand ambassador yang tepat dan berpengaruh kepada pelanggan yang akan menggunakan jasa layanan dari Ruangguru.

3. Strategi profil atau profile strategy dilakukan untuk membangun brand image yang ditujukan kepada stakeholder perusahaan. Hal ini menjadi poin penting karena pihak perusahaan Ruangguru memilih brand ambassador di tahun ini dengan memerhatikan strategi profil. Pemilihan brand ambassador tidak sekadar dilakukan untuk mempromosikan saja,
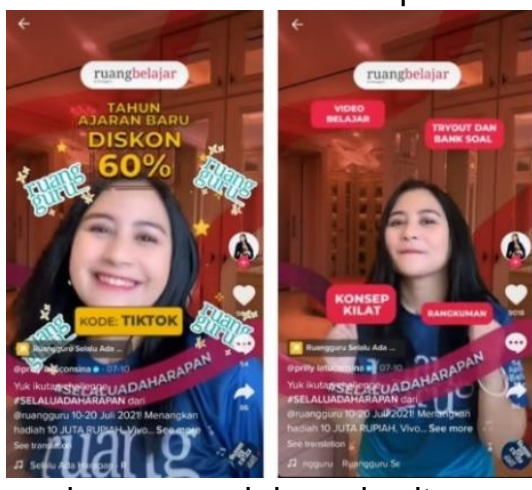

tetapi

juga akan

berpengaruh kepada citra perusahaan. Seperti pemilihan aktris Prilly Latuconsina.

Salah satu Brand Ambassador Ruangguru di tahun 2021 ini adalah Prilly latuconsina. Akttis cantik yang sangat digandrungi karena prestasi dan juga kemampuan dalam berakting ini turut menjadi bagian dari Ruangguru. Sebagai artis yang memiliki banyak penggemar, keberadaan Prilly sebagai Brand Ambassador Ruangguru akan mampu mengajak para pengikutnya untuk bergabung dengan Ruangguru dan menjaga serta meningkatkan citra perusahaan.
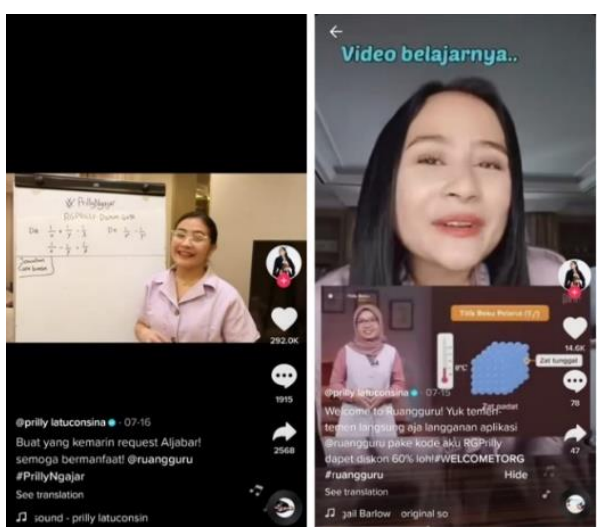

Gambar 3. Prilly sebagai brand ambassador Ruangguru tengah melakukan promosi di akun TikTok miliknya

(Sumber:www.tiktok.com/prillylatuconsina15)

Dalam melaksanakan tugasnya sebagai Brand Ambassador Ruangguru, ditengah pandemi Covid-19 Prilly kerap melakukan sharing informasi mengenai pendidikan dan Ruangguru pada akun media 
sosial miliknya, seperti Instagram dan TikTok. Prilly menggunakan hastag \#prillyngajar sebagai program atau content media dalam upaya strategi komunikasi pemasarannya. Dalam akun TikToknya, Prilly berbagi cara cepat untuk mengerjakan soal-soal Matematika. Adapun salah satu unggahan saat \#prillyngajar dilakukan, yakni seperti pada gambar di bawah ini:

Gambar 4. Prilly sebagai brand ambassador

Ruangguru tengah mengunggah konten

\#PrillyNgajar di akun media sosial TikTok

(Sumber:www.tiktok.com/prillylatuconsina15)

Di tengah pandemi seperti ini, pembelajaran dengan video tutorial seperti
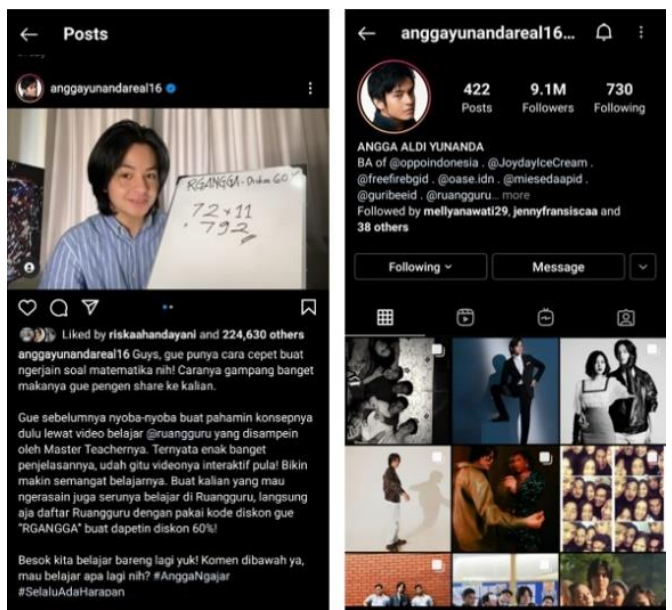

yang dilakukan oleh Prilly merupakan hal yang berguna untuk memberikan edukasi kepada pelajar di media sosial. Pembawaan yang santai dan menarik sangat diperlukan dalam melakukan upaya strategi komunikasi pemasaran tersebut. Terlebih penyebaran informasi menggunakan media sosial yang dapat dijangkau oleh semua kalagan sangat menguntungkan pihak penyedia konten, sehingga penerimaan informasi oleh masyarakat sebagai target dapat diterima secara tepat.

Selain Prilly Latuconsina, aktor muda tampan Angga Yunanda, juga turut bergabung menjadi Brand Ambassador Ruangguru. Angga yang saat ini tengah naik daun karena usai membintangi berbagai web series itupun ternyata juga memiliki kemampuan untuk mengajar. Dalam unggahan di laman instagramnya, Angga mengajak para pemgikutnya untuk lebih banyak berlatih soal khususnya Matematika.

Gambar 5. Angga Yunanda mengunggah konten \#AnggaNgajar pada laman Instagramnya

(Sumber:www.instagram.com/anggayunandar eal16)

Tidak sekadar mengajar, aktor dengan jumlah pengikut mencapai 9,1 Juta ini juga kerapkali memberikan langkah singkat atau cara cepat dalam menyelesaikan suatu pertanyaan pada pelajaran Matematika. Pemilihan brand ambassador dari kalangan artis, content creator, dan juga selebriti terkenal sangat berpeluang besar dalam upaya strategi komunikasi pemasaran suatu brand. Keberadaan para brand ambassador yang sudah dikenal oleh semua kalangan akan mempermudah Ruangguru dalam menjangkau masyarakat. Tidak hanya itu, berbagai bidang yang dikuasai oleh brand ambassador juga menjadikan Ruangguru dapat dikenal melalui berbagai lini kehidupan.

\section{Respon masyarakat terhadap penetapan Brand Ambassador Ruangguru Tahun 2021}

Sebelum ditetapkannya kelima new brand ambassador Ruangguru, pada tahun 2020, Ruangguru menetapkan lqbal Ramadhan, Gita Savitri, Jefri Nichol, The Onsu Family sebagai brand ambassador Ruangguru atau lebih dikenal dengan sebutan Ruangguru Squad. Berdasarkan hasil penelitian yang dilakukan oleh (Anjarsari \& Hendriyani, 2021), penetapan brand ambassador memengaruhi keputusan berlangganan Ruangguru sebesar $85,4 \%$. Besaran persentase tersebut juga dipengaruhi oleh lingkungan sosial yang mendukung penggunaan aplikasi Ruangguru dan terpaan iklan yang gencar dilakukan oleh pihak Ruangguru bersama dengan brand ambassador yang bertugas. Berdasarkan hasil penelitian terdahulu tersebut, maka seorang brand ambassador juga berperan penting dalam meningkatkan ketergantungan individu terhadap media massa (baca: Instagram, TikTok) dengan terus memberikan konten berupa video edukasi kreatif kepada pengguna, khususnya pelajar sehingga muncul stimuli yang akan berlanjut menjadi tindakan (baca: keputusan berlangganan) di Ruangguru.

Jika dianalisa berdasarkan komentarkomentar netizen atau masyarakat pengguna media sosial pada laman Instagram, Twitter, dan YouTube. Terdapat beberapa respon positif yang diambil dari unggahan laman Instagram milik new brand ambassadors Ruangguru 2021. Respon positif tersebut tentunya dipengaruhi oleh bagaimana brand ambassador tersebut bersikap dan berucap di media sosial maupun pada kehidupan nyatanya. Dengan adanya banyak respon positif yang didapatkan oleh pihak brand ambassador maupun Ruangguru sendiri, maka meningkatkan peluang masyarakat dalam memilih aplikasi yang hendak digunakan sebagai media pembelajarannya. Berikut tangkapan layar dari beberapa respon positif 
yang didapatkan oleh brand ambassador maupun Ruangguru dalam unggahan pada laman Instagram.

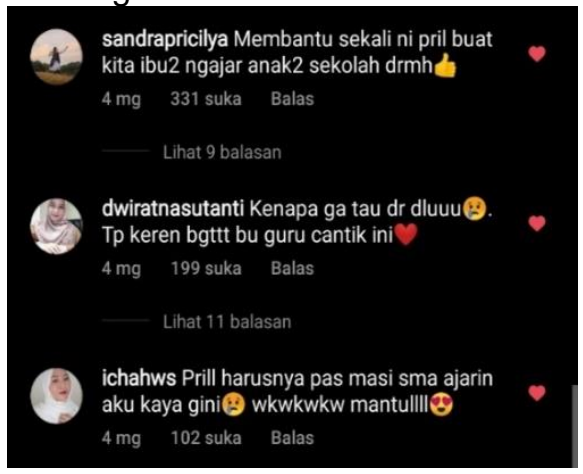

Gambar 6. Komentar masyarakat saat Prilly diumumkan menjadi brand ambassador Ruangguru (Sumber:www.instagram.com/prillylatuconsina 96)

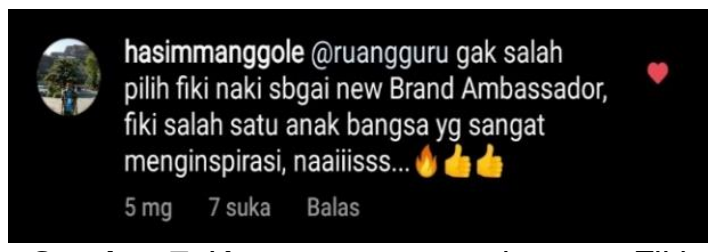

Gambar 7. Komentar masyarakat saat Fiki Naki diumumkan menjadi brand ambassador Ruangguru

(Sumber: www.instagram.com/fikinakii)

Selain melihat bagaimana respon positif masyarakat terhadap berita penetapan new brand ambassador Ruangguru 2021, penulis juga melakukan kegiatan wawancara secara daring terhadap pengguna aplikasi Ruangguru yang berasal dari Sekolah Dasar Negeri 3 Peguyangan Denpasar. Dari hasil wawancara bersama orang tua siswa, dapat disimpulkan bahwasanya pengguna

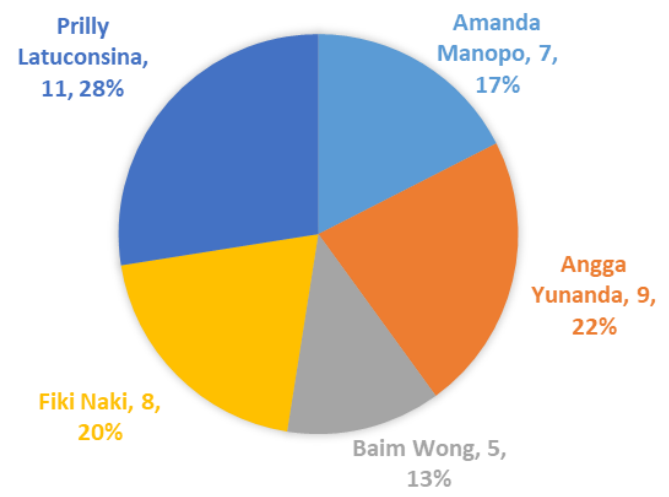

Ruangguru sangat puas akan layanan yang diberikan dan setuju akan penetapan kelima new brand ambassadors Ruangguru tahun 2021. Alasannya adalah karena masingmasing brand ambassador memiliki kekuatan dan digital platform yang besar dan dipandang mampu merepresentasikan generasi muda yang cerdas dan berbakat, sehingga mampu menjadi suri teladan generasi millennial dan gen $Z$ saat ini.

Menurut Pradia Vijayanti (11) yang merupakan siswa kelas 6 SD di SDN 3 Peguyangan menyebutkan bahwasanya pembelajaran dengan menggunakan aplikasi Ruangguru pada saat pandemi Covid-19 sangat mampu mendorong kemampuan belajarnya menjadi lebih optimal. Terkait dengan pemilihan Brand Ambassador Ruangguru tahun 2021, Pradia menuturkan bahwasanya menjadi lebih tertarik menggunakan Ruangguru karena kini Prilly Latuconsina ikut bergabung didalamnya.

Gambar 8. Persentase Ketepatan Pemilihan Brand Ambassador Ruangguru 2021

(Sumber: data kuisioner pribadi, 2021)

Berdasarkan atas hasil kuisioner yang telah dibagikan secara online, dapat diberikan kesimpulan bahwasanya banyak responden yang menyetujui pemilihan kelima brand ambassadors Ruangguru yang berasal dari kalangan artis dan content creator tersebut. Dari 40 responden, sebanyak 11 orang atau $28 \%$ yang memilih Prilly Latuconsina sebagai Brand Ambassador yang paling tepat sebagai ikon Ruangguru. Alasan terbanyak adalah karena selain sudah berkarir di dunia entertainment sejak belia, Prilly juga tekun dalam belajar di sekolah dan kini tengah mengenyam pendidikan Strata 1 (S1) di LSPR Jakarta. Kendati persentase Baim Wong hanya memperoleh suara sebanyak $13 \%$ dari total keseluruhan responden, data menunjukkan bahwasanya pengikut Baim Wong berasal dari lebih banyak variasi usia dan tidak hanya seorang remaja, namun juga orang tua.

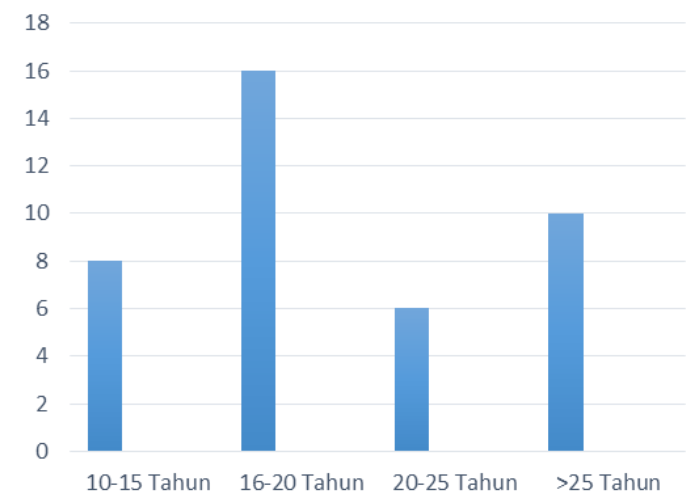

Gambar 9. Data usia responden (Sumber: data kuisioner pribadi, 2021)

\section{SIMPULAN DAN SARAN}

Penetapan brand ambassador sebagai 
alat dan media strategi komunikasi pemasaran pada perusahaan Ruangguru dinilai efektif karena mampu menjadi komunikator dalam penyampaian informasi mengenai layanan yang ditawarkan oleh Ruangguru. Selain itu, fungsi daripada brand ambassador adalah sebagai pelaku yang berperan untuk meningkatkan brand awareness melalui strategi menarik dan mendorong calon pengguna layanan untuk ikut bergabung menjadi keluarga Ruangguru.

Penggunaan media sosial sebagai digital platform promosi Ruangguru merupakan strategi pemasaran yang efektif karena mampu meningkatkan arus komunikasi secara berkala antara penyedia dan pengguna layanan Ruangguru. Dengan komunikasi yang dilakukan secara terus menerus, maka memungkinkan adanya penanaman brand awareness dan kekayaan informasi yang diperoleh oleh pengguna maupun calon pengguna aplikasi Ruangguru.

Penetapan kelima new brand ambassador Ruangguru tahun 2021 yakni Amanda Manopo, Angga Yunanda, Baim Wong, Fiki Naki, dan Prilly Latuconsina disambut sangat baik oleh masyarakat awam maupun pengguna layanan Ruangguru. Hal tersebut dikarenakan adanya reputasi yang baik dari masing-masing brand ambassador dan perolehan prestasi yang selama ini didapatkan oleh kelima brand ambassador. Dengan kekuatan digital platform yang dimiliki oleh kelima brand ambassador tersebut diharapkan mampu meningkatkan reputasi Ruangguru di mata publik.

Sejauh ini, pemilihan brand ambassadors Ruangguru telah dilakukan dengan baik. Hanya saja pada tahun 2020, salah satu brand ambassador dihadapkan pada isu negatif di tengah masyarakat. Hal tersebut tentunya menganggu dan dapat mengancam reputasi Ruangguru. Oleh sebab itu, penulis dapat menyarankan adanya screening lebih dalam pada awal penetapan brand ambassador dan melakukan pendekatan secara personal kepada calon brand ambassador agar dalam masa kontraknya tidak melakukan hal-hal yang dapat merugikan pihak perusahaan. Adapun saran teoritis dan praktis yang dapat diberikan adalah sebagai berikut:

1. Saran Teoritis

Berdasarkan hasil analisis yang dilakukan dalam penelitian dan pengabdian masyarakat ini, penulis dapat menyarankan peneliti selanjutnya untuk mengkaji pengaruh brand ambassador Ruangguru tahun 2021 terhadap minat belajar di tengah pandemi Covid-19 lebih mengkhususkan kepada jenjang akhir di
Sekolah Menengah Pertama (SMP) atau Sekolah Menengah Atas (SMA) agar lebih memperoleh hasil efektivitas yang dapat melengkapi hasil analisis yang telah dibuat ini. Selain itu, untuk peneliti selanjutnya diharapkan mampu menggunakan metode penelitian kuantitatif dengan dukungan data hasil nilai ujian maupun data pendukung lainnya untuk memperkuat hasil pengaruh atau peranan dari brand ambassador Ruangguru dalam melakukan kegiatan promosi di media massa.

2. Saran Praktis

Dikarenakan permasalahan utama dalam pembelajaran saat pandemi Covid-19 ini adalah sulitnya siswa memahami materi belajar dengan baik karena kurangnya media belajar kreatif yang ada, maka untuk lembaga pendidikan diharapkan mampu berinovasi dengan menciptakan video edukasi yang kreatif atau sebaiknya bekerja sama dengan pihak penyedia layanan bimbingan belajar, seperti Ruangguru. Selain itu, penerapan pembelajaran selama masa pandemi Covid-19 dapat dilakukan dengan mengacu pada Surat Edaran Nomor 15 Tahun 2020 oleh Kemendikbud yang menjelaskan terkait proses kegiatan pembelajaran secara rinci, salah satu diantaranya adalah kegiatan pembelajaran dapat dilaksanakan secara daring dengan memperhatikan materi pembelajaran yang bersifat inklusif sesuai dengan usia dan jenjang pendidikan, konteks budaya, karakter dan jenis kekhususan peserta didik. Merujuk pada hal tersebut, maka saran yang dapat diberikan kepada Ruangguru adalah lebih meningkatkan keberagaman materi pembelajaran dan meningkatkan kualitas audio-visual konten video pembelajaran serta sesuai dengan arahan Pemerintah Indonesia, yakni berbasis konteks kebudayaan dan membangun pendidikan karakter.

\section{UCAPAN TERIMAKASIH}

Dalam penyusunan laporan ini, penulis banyak mendapatkan saran dan dorongan dari berbagai pihak, sehingga pada kesempatan ini perkenankanlah penulis mengucapkan terima kasih sebesar-besarnya kepada:

1. Prof. Dr. Ir. Nyoman Sri Subawa, S.T., S.Sos., M.M., IPM. Selaku Rektor Universitas Pendidikan Nasional.

2. Pihak PT. Ruang Raya Indonesia (Ruangguru) yang telah memberikan kesempatan untuk melakukan analisis terkait new brand ambassador of Ruangguru 2021. 
3. Ir. I Wayan Sutama, M.T., IPM. Selaku Head of Institute for Research and Community Services Universitas Pendidikan Nasional.

4. Dr. Ni Nyoman Juwita Arsawati, S.H., M.Hum. selaku Dekan Fakultas Hukum dan IImu Sosial Universitas Pendidikan Nasional.

5. Ir. Adie Wahyudi Oktavia Gama, S.T., M.T., IPM., ASEAN Eng. Selaku Head of Research and Journal Publication Universitas Pendidikan Nasional.

6. Kepala Program Studi, Nuning Indah Pratiwi, S.Sos., M.I.Kom.

7. Dosen Pembimbing, Ni Luh Putu Sariani, S.E., M.M.

8. Pemilik jurnal-jurnal terkait pembahasan mengenai Ruangguru

9. Ibu tercinta, I Gusti Ayu Putu Winny Surya Westriari,

10. Responden yang berlangganan aplikasi Ruangguru, dan

11. Teman-teman IImu Komunikasi Angkatan 2018 tercinta yang tidak bisa disebutkan satu per satu.

\section{DAFTAR RUJUKAN}

Afif, N. (2019). Pengajaran dan Pembelajaran di Era Digital. IQ (Ilmu Al-Qur'an): Jurnal Pendidikan Islam, 2(01), 117-129. https://doi.org/10.37542/iq.v2i01.28

Agustin, M. (2020). Implementasi Teknologi Pendidikan Berbasis Digital dalam Peningkatan Minat dan Prestasi Belajar Siswa: (Studi Kasus Pada Start-Up Bimbingan Belajar dalam Jaringan Ruangguru di Kota Yogyakarta) [Institut Agama Islam Negeri Ponorogo]. http://etheses.iainponorogo.ac.id/12265/1 /MUFIDA

AGUSTIN_210616210_PGMI.pdf

Anjarsari, D. F., \& Hendriyani, C. T. (2021). Pengaruh Brand Ambassador, Brand Image, Terpaan Iklan, dan Lingkungan Sosial Terhadap Keputusan Berlangganan. Universitas Sebelas Maret. http://www.jurnalkommas.com/docs/Jurna I D0216027.pdf

Basar, A. M. (2021). Problematika Pembelajaran Jarak Jauh Pada Masa Pandemi Covid-19. Edunesia: Jurnal Ilmiah Pendidikan, 2(1), 208-218. https://doi.org/10.51276/edu.v2i1.112

Caturini, R. (2018). Perluas Pasar, Ruangguru Teken Kerja Sama dengan Pemkab Banyuwangi. Kontan.Co.ld. https://industri.kontan.co.id/news/perluaspasar-ruangguru-teken-kerja-samadengan-pemkab-banyuwangi

Hidayat, M. (2020). Ruangguru Dapuk 4 Brand
Ambassador Baru. Liputan6.Com. https://www.liputan6.com/tekno/read/414 7301/ruangguru-dapuk-4-brandambassador-baru

Joo-Young, J., \& Moro, M. (2012). Cross-Level Analysis of Social Media: Toward the Construction of an Ecological Framework. $J$ Soc Sci, 53-74.

Surat Edaran Nomor 15 Tahun 2020, Pub. L. No. Surat Edaran Nomor 15 Tahun 2020, Surat Edaran Nomor 15 Tahun 20201 (2020).

https://www.kemdikbud.go.id/main/files/d ownload/27bdb5850ac3939

Krisnawati. et all, E. (2016). Studi Kasus Perilaku Remaja di Kota Salatiga dalam Penggunaan Media. Komunikatif, 5(1), 43-69.

https://media.neliti.com/media/publication s/232180-perilaku-konsumsi-media-olehkalangan-re-9a678f21.pdf

Kurniandari, R. (2018). Bikin Bangga! Kurang dari 2 Tahun, Iqbaal Ramadhan Lulus Pendidikan di AS, Begini Potretnya Artikel ini telah tayang di TribunJakarta.com dengan judul Bikin Bangga! Kurang dari 2 Tahun, lqbaal Ramadhan Lulus Pendidikan di AS, Begini Potretnya. TribunJakarta.Com.

https://jakarta.tribunnews.com/2018/05/2 1/bikin-bangga-kurang-dari-2-tahuniqbaal-ramadhan-lulus-pendidikan-di-asbegini-potretnya

Lea-Greenwood, G. (2013). Fashion Marketing Communications E-book. Somerset, NJ, USA: Wiley.

Moriansyah, L. (2015). Pemasaran Melalui Media Sosial: Antecedents Dan Consequences. Jurnal Penelitian Komunikasi Dan Opini Publik, 19(3), 187196.

https://media.neliti.com/media/publication s/124068-ID-none.pdf

Muhamad, S. V. (2021). Pandemi Covid-19 Sebagai Persoalan Serius Banyak Negara di Dunia. Info Singkat: Kajian Singkat Terhadap Isu Aktual Dan Strategis, XIII(13), 7-12. https://berkas.dpr.go.id/puslit/files/info_si ngkat/Info Singkat-XIII-13-I-P3DI-Juli2021-183.pdf

Pakpahan, S. P. (2011). Gaya Belajar Dan Strategi Belajar Mahasiswa Universitas Terbuka Unit Program Belajar Jarak Jauh Medan. Jurnal Pendidikan Terbuka Dan Jarak Jauh, 12(1), 49-65. http://www.jurnal.ut.ac.id/index.php/jptjj/ar ticle/view/441/425

Puspitasari, A. (2021). 5 Brand Ambassador Baru Ruangguru untuk Temani Belajar 
Makin Seru. Ruangguru.Com. https://www.ruangguru.com/blog/brandambassador-baru-ruangguru

Putra, M. (2014). Pengaruh Brand Ambassador Terhadap Brand Image Serta Dampaknya Terhadap Keputusan Pembelian (Survey pada pengguna LINE di Asia). Jurnal Administrasi Bisnis $S 1$ Universitas Brawijaya, $\quad$ 12(1), 83211. http://administrasibisnis.studentjournal.ub .ac.id/index.php/jab/article/view/497

Sarastuti, D. (2017). Strategi Komunikasi Pemasaran Online Produk Busana Muslim Queenova. Visi Komunikasi, 16(01), 71-90. https://publikasi.mercubuana.ac.id/index. php/viskom/article/download/1645/1255

Setiawati, N. S. R. dan 2Mia. (2019). Aplikasi Pendidikan Online "Ruang Guru" Sebagai Peningkatan Minat Belajar Generasi Milenial Dalam Menyikapi Perkembangan Revolusi Industri 4.0. Seloka: Jurnal Pendidikan Bahasa Dan Sastra Indonesia, 3(2), 241-246. https://jurnal.uisu.ac.id/index.php/Bahastr a/article/view/3179

Shoumi, A. Z. (2019). Peran Multimedia Dalam Pendidikan Pada Aplikasi Ruang Guru. Prosiding Seminar Nasional Cendekiawan, 2.23.1-2.23.6.

https://doi.org/10.25105/semnas.v0i0.580 9

Susanti, E., Harta, R., Karyana, A., \& Halimah, M. (2018). Desain Video Pembelajaran Yang Efektif Pada Pendidikan Jarak Jauh: Studi Di Universitas Terbuka. Jurnal Pendidikan Dan Kebudayaan, 3(2), 167185.

https://doi.org/10.24832/jpnk.v3i2.929 